\title{
Pengaruh Kualitas Produk terhadap Kepuasan Konsumen Sepeda Motor NMAX pada PT Yamaha A. Rivai Palembang
}

\author{
Abdul Rahman Raka Aditia ${ }^{1)}$, Muhammad Wadud ${ }^{2)}$, M. Kurniawan, DP ${ }^{3)}$ \\ 1) Universitas Indo Global Mandiri \\ Jl. Jend. Sudirman No. 629 KM.4 Palembang Kode Pos 30129

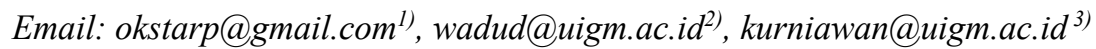

\begin{abstract}
Abstrak
Penelitian ini bertujuan untuk mengukur pengaruh kualitas produk terhadap kepuasan konsumen sepeda motor NMAX pada PT Yamaha A. Rivai Palembang. Teknik sampling yang digunakan adalah accidental sampling dengan responden akhir berjumlah 50. Data dikumpulkan menggunakan kuesioner dan wawancara dan dianalisis menggunakan regresi linier sederhana pada SPSS V22. Hasil pengukuran menunjukkan bahwa kualitas produk memiliki thitung $>t_{\text {tabel }}(15.209>2.01)$ dan taraf signifikansi $(0,000<0,05)$. Ini dapat disimpulkan bahwa kualitas produk berpengaruh secara signifikan terhadap kepuasan konsumen. Hasil uji koefisien korelasi (R) adalah sebesar 0,910 yang berarti hubungan antara kualitas produk dengan kepuasan konsumen adalah sangat kuat (91\%). Koefisiendeterminasi $\left(\mathrm{R}^{2}\right)$ sebesar 0,828 yang berarti besarnya kontribusi kualitas produk bisa menjelaskan kepuasan konsumen sebesar $82,8 \%$ sisanya sebesar $17,2 \%$ dipengaruhi oleh variabel lain yang tidak dimasukkan dalam penelitin ini.
\end{abstract}

Kata Kunci: kualitas produk, kepuasan konsumen, perilaku konsumen

\section{Pendahuluan}

Seiring dengan dunia bisnis otomotif di Indonesia membuat persaingan bisnis menjadi semakin tajam, karena makin banyaknya produk yang memiliki berbagai macam kualitas yang dikeluarkan, akibatnya konsumen menjadi semakin kritis dalam melakukan pembelian produk yang memiliki kualitas terbaik. Tingkat kepuasan konsumen terhadap suatu produk akan memberikan cerminan keberhasilan produsen dalam menghasilkan produk tersebut. Dinamika dalam persaingan usaha yang semakin pesat dalam menghasilkan dan menjual produk berkualitas, memberikan tantangan tersendiri bagi perusahaan agar dapat memberikan peluang untuk dapat bertahan dimasa yang akan datang. Perusahaan harus meningkatkan kualitas produknya agar konsumen merasakan sebuah kepuasan terhadap produk tersebut.

Kualitas produk memiliki arti penting bagi perusahaan karena tanpa adanya kualitas produk, perusahaan tidak akan dapat melakukan apapun dari usahanya. Pada dasarnya dalam membeli suatu produk, seorang pelanggan tidak hanya membeli produk, akan tetapi pelanggan juga membeli manfaat atau keunggulan yang dapat diperoleh dari produk yang dibelinya.

Menurut Kotler dan Keller (2016:156) kualitas produk adalah totalitas fitur dan karakteristik suatu produk atau layanan yang memiliki kemampuan untuk memuaskan yang disebutkan atau kebutuhan tersirat. Setiap perusahaan yang menginginkan dapat memenuhi kebutuhan dan keinginan pelanggan, maka akan berusaha membuat produk yang berkualitas, yang ditampilkan baik melalui ciri-ciri luar (design) produk maupun inti (core) produk itu sendiri. Oleh karena itu, suatu produk harus memiliki keunggulan dari produk-produk yang lain, salah satunya dari segi kualitas produk yang ditawarkan. Kualitas produk merupakan salah satu kunci untuk mencapai kepuasan terhadap konsumen yang merasakannya. 
Kepuasan konsumen merupakan salah satu faktor penentu keberhasilan perusahaan, selain itu kepuasan konsumen dapat menjadi alat bersaing bagi suatu perusahaan dalam menghadapi pesaingnya. Menurut Nugroho (2015:162) menjelaskan bahwa kepuasan konsumen merupakan salah satu elemen penting dalam peningkatan kinerja pemasaran dalam suatu perusahaan. Kepuasan yang dirasakan oleh pelanggan dapat meningkatkan intensitas membeli dari pelanggan tersebut. Dengan terciptanya tingkat kepuasan pelanggan yang optimal maka mendorong terciptanya loyalitas di benak pelanggan yang merasa puas.

Kualitas produk memiliki hubungan yang erat dengan kepuasan konsumen. Kualitas produk memberikan suatu dorongan kepada konsumen untuk menjalin ikatan hubungan yang kuat dengan perusahaan. Dalam jangka panjang ikatan seperti ini memungkinkan perusahaan untuk memahami dengan seksama harapan pelanggan serta kebutuhan mereka. Dengan demikian, perusahaan dapat meningkatkan kepuasan pelanggan dimana perusahaan memaksimumkan pengalaman pelanggan yang menyenangkan dan meminimunkan pengalaman pelanggan yang kurang menyenangkan menurut Tjiptono (2012).

\section{Tinjauan Pustaka}

\subsection{Pengertian Pemasaran}

Menurut Kotler dan Keller (2009, p. 5) Pemasaran (marketing) adalah mengidentifikasi dan memenuhi kebutuhan manusia dan sosial. Manajemen pemasaran (marketing manajement) adalah sebagai seni dan ilmu memilih pasar sasaran dan meraih, mempertahankan serta menumbuhkan pelanggan dengan menciptakan, menghantarkan, dan mengomunikasikan nilai pelanggan yang unggul. Pada proses pemasaran terdapat individu yang berlaku sebagai pemasar.

\subsection{Bauran Pemasaran}

Dalam pemasaran terdapat strategi pemasaran yang disebut bauran pemasaran atau marketing mix yang memiliki peranan penting dalam mempengaruhi konsumen agar membeli suatu produk atau jasa yang ditawarkan oleh perusahaan. Menurut Kotler dan Keller (2016) menyatakan bahwa bauran pemasaran merupakan seperangkat alat pemasaran yang digunakan suatu perusahaan untuk terus menurus mencapai tujuan pemasaran dipasar sasaran. Bauran pemasaran merupakan strategi yang dijalankan perusahaan yang berkaitan dengan penentuan bagaimana perusahaan menyajikan penawaran produk pada satu segmen pasar tertentu yang merupakan sasaran pasarannya. Sedangkan menurut Buchari Alma (2016) bauran pemasaran adalah strategi mencampur kegiatan-kegiatan marketing agar dicari kombinasi maksimal sehingga mendatangkan hasil paling memuaskan.

\subsection{Pengertian Kualitas Produk}

Kotler dan Armstrong (2010:236) mendefinisikan produk sebagai segala sesuatu yang dapat ditawarkan kepada pasar agar menarik perhatian, akuisisi, penggunaan, atau konsumsi yang dapat memuaskan suatu keinginan atau kebutuhan. Menurut Alma (2016:139) produk adalah segala sesuatu yang dapat ditawarkan di pasar, untuk memuaskan kebutuhan dan keinginan konsumen. Produk terdiri atas barang, jasa, pengalaman, events, orang, tempat, kepemilikan, organisasi, informasi dan ide. Sedangkan menurut Tjipton dan Chandra (2012: 95) produk ialah Segala sesuatu yang dapat ditawarkan produsen untuk diperhatikan, diminta, dicari, dibeli, digunakan atau dikonsumsi pasar sebagai pemenuhan kebutuhan atau keinginan pasar yang bersangkutan. 


\subsection{Pengertian Kepuasan Konsumen}

Pada dasarnya tujuan dari suatu bisnis adalah untuk menciptakan konsumen yang merasa puas. Terciptanya kepuasan konsumen dapat memberikan manfaat yang baik bagi perusahaan dan memberikan dasar yang baik bagi pembeli sehingga terciptanya kepuasan konsumen dan membentuk suatu rekomendasi dari mulut kemulut (word of-mouth) yang menguntungkan bagi perusahaan. Menurut adji dan Sopiah (2013:180) menjelaskan bahwa kepuasan atau ketidak puasan adalah perasaan senang atau kecewa seseorang yang berasal dari perbandingan antara kesannya terhadap kinerja produk yang real atau actual dengan kinerja produk yang diharapkan. Sangat dibutuhkan penelitian untuk membuktikan ada atau tidaknya harapan sebelumnya yang merupakan bagian terpenting dalam kepuasan.

\subsection{Penelitian Terdahulu}

Berdasarkan penelitian (Purnomo Edwin Setyo) dengan judul Pengaruh kualitas produk dan harga terhadap kepuasan konsumen "Best Autoworks" Mengacu pada hasil pembahasan yang telah dilakukan maka dapat disimpulkan beberapa hal berikut ini: Kualitas produk berpengaruh secara signifikan terhadap kepuasan konsumen Best Autoworks, hal ini sesuai dengan penelitian terdahulu yang sudah dilakukan. Hasil dari uji t menunjukan nilai Sig yaitu sebesar 0,000 . Hal tersebut menunjukkan bahwa hipotesis penelitian yang menyatakan kualitas produk secara parsial berpengaruh signifikan terhadap kepuasan konsumen di Best Autoworks dapat diterima kebenarannya. Harga berpengaruh secara signifikan terhadap kepuasan konsumen Best Autoworks, hal ini sesuai dengan penelitian terdahulu yang sudah dilakukan. Namun, hasil dari uji t menunjukkan nilai Sig yaitu sebesar 0,054. Hal tersebut menunjukkan bahwa hipotesis penelitian yang menyatakan harga secara parsial tidak berpengaruh signifikan terhadap kepuasan konsumen di Best Autoworks dapat diterima kebenarannya.

Dalam sebuah penelitian (Sony Mahendra) dengan judul Pengaruh kualitas produk dan harga terhadap kepuasan konsumen Honda Beat. Mengacu pada kesimpulan bahwa dari hasil uji $\mathrm{F}$ yang telah dilakukan dapat diketahui bahwa kualitas produk (X1) dan harga (X2) mempunyai pengaruh yang signifikan secara simultan terhadap kepuasan konsumen Honda Beat di Kecamatan Trenggalek Kabupaten Trenggalek. Hasil uji t yang telah dilakukan juga dapat diketahui bahwa kualitas produk (X1) dan harga (X2) mempunyai pengaruh signifikan secara parsial terhadap kepuasan konsumen Honda Beat di Kecamatan Trenggalek Kabupaten Trenggalek. Sedangkan variabel yang dominan yang mempengaruhi kepuasan konsumen Honda Beat di Kecamatan.

\subsection{Kerangka Pemikiran}

Gambar 1. Kerangka Pemikiran

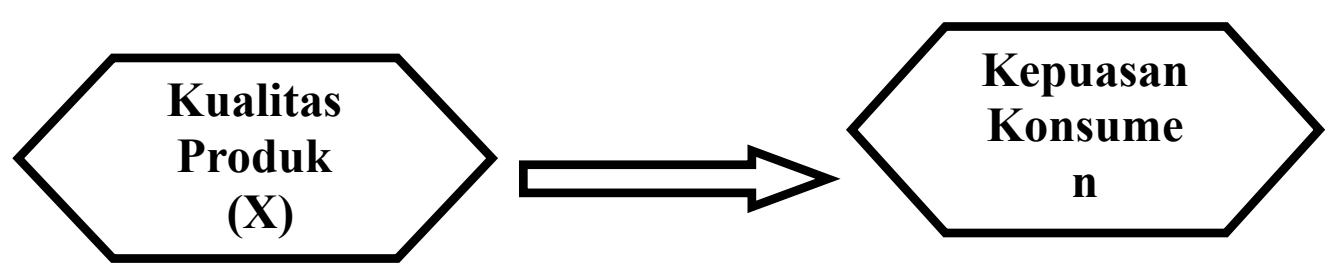

Berdasarkan gambar kerangka pemikiran diatas, maka dapat diketahui yang menjadi variabel independen/Variabel bebas adalah Kualitas Produk (X) dan yang menjadi variabel 
dependen/variabel terikat adalah Kepuasan Konsumen (Y).

\subsection{Hipotesis}

Berdasarkan rumusan masalah dan kerangka pemikiran di atas maka dapat dibuat Hipotesis sebagai berikut: "Diduga terdapat Pengaruh Kualitas Produk Terhadap Kepuasan Konsumen Sepeda Motor NMAX Pada PT. Yamaha A. Rivai Palembang".

\section{Metodologi}

Penelitian ini akan membahas masalah yang berkaitan dengan Kualitas Produk Terhadap Kepuasan Konsumen Sepeda Motor Yamaha NMAX pada PT.Yamaha A. Rivai Palembang. Apakah pengaruh kualitas produk terhadap kepuasan konsumen berpengaruh secara signifikan dalam perusahaan. Adapun objek penelitian dalam skripsi ini adalah Kualitas Produk (X) sebagai variabel bebas atau variabel independen dan Kepuasan Konsumen (Y) sebagai variabel terikat atau variabel dependen. Penelitian ini dilakukan pada perusahaan PT. Yamaha A. Rivai Palembang.

Waktu yang digunakan dalam penelitian ini kurang lebih selama 4 bulan yakni mulai pada bulan januari sampai dengan April 2020, Penelitian ini dilaksanakan pada PT. Yamaha A. Rivai Palembang "Beralamatkan di J1. Kapten A. Rivai No. 9, Sungai Pangeran kec. Ilir Timur I, Kota Palembang, Sumatera Selatan 30129.

Jenis data data dalam penelitian ini menurut Sugiyono(2016) jenis data dibedakan menjadi 2 jenis antara lain:

1. Data kualitatif adalah data yang berbentuk kata, skema, dan gambar. Data kualitatif penelitian ini berupa nama dan alamat objek penelitian (Sugiyono, 2016).

2. Data kuantitatif adalah data yang berbentuk angka atau data kualitatif yang diangkakan (Sugiyono, 2016). Data kuantitatif penelitian ini berupa kuisioner pada konsumen speda motor NMAX yang ada pada PT. Yamaha A. Rivai Palembang berupa angka.

Sumber data dalam penelitian ini menggunakan data :

1. Data primer menurut Sugiyono (2016) adalah sumber data yang langsung memberikan data kepada pengumpul data (konsumen pada PT.Yamaha A. Rivai Palembang). Data primer diperoleh dari menyebar kuesioner, observasi, dan juga data hasil wawancara peneliti dengan narasumber.

2. Data sekunder menurut Sugiyono (2016) adalah sumber data yang tidak langsung memberikan data kepada pengumpul data, misalnya lewat orang lain atau lewat dokumen.

Teknik pengumpulan data yang dilakukan dalam penelitian ini antara lain:

1. Kuesioner

Teknik pengumpulan data dengan menyebarkan daftar pertanyaan yang diberikan kepada responden untuk dijawabnya.

2. Wawancara

Teknik pengumpulan data yang dilakukan tatap muka dan tanya jawab langsung antara peneliti dan narasumber.

Menurut Sugiyono (2014) populasi Merupakan wilayah generalisasi yang terdiri atas : Objek atau subjek yang mempunyai kualitas dan karakteristik tertentu yang diharapkan oleh peneliti 
untuk mempelajari dan ditarik kesimpulannya. Populasi pada penulisan ini sebanyak 50 konsumen sepeda motor Yamaha NMAX pada PT Yamaha A. Rivai Palembang selama priode januari-Maret 2020 menggunakan tehnik accidental sampling adalah tehnik penentuan sampel berdasarkan kebetulan, yaitu konsumen yang secara kebetulan/incidental bertemu dengan peneliti dapat digunakan sebagai sampel.

Populasi dalam penelitian ini meliputi konsumen sepeda motor Yamaha NMAX sebanyak 50 konsumen yang ada pada PT. Yamaha A. Rivai Palembang. Sampel dalam penelitian ini menggunakan teknik Nonprobablility sampling dengan metode Sampel Jenuh dimana semua anggota populasi digunakan sebagai sampel. Hal tersebut dikarenakan jumlah populasi yang relative kecil. Sehingga dapat menjawab permasalahan penelitian Kualitas Produk Terhadap Kepuasan konsumen Sepeda Motor Yamaha NMAX pada PT. A. Rivai Palembang.

Dalam penelitian ini penulis menggunakan metode data kuantitatif. Teknik analisis data yang digunakan sudah jelas yaitu diurutkan untuk menjawab rumusan masalah dan menguji hipotesis yang telah dirumuskan. Adapun tahapan analisis kuantitatif yang digunakan untuk menganalisis data dalam penelitian ini adalah:

\subsection{Uji Validitas}

Uji validitas dilakukan untuk mengetahui apakah alat ukur tersebut memiliki ketepatan dalam melakukan pengukuran, atau dengan kata lain apakah alat ukur tersebut dapat benar-benar mengukur apa yang hendak diukur (Arikunto, 2013). Cara pengejian validitas dengan menghitung korelasi antar skor masing-masing pertanyaan dan skor total dengan menggunakan korelasi product moment pada taraf kepercayaan $\mathrm{a}=0,05$. Koefisien validitas yang memuaskan jika nilai $r \leq 0,00$. Sedangkan untuk menghasilkan indeks atau angka yang koefisien validitas digunakan program SPSS.

\subsection{Uji Reliabilitas}

Data untuk mengukur suatu kuesioner yang merupakan indikator dari variable atau konstruk. Suatu kuesioner dikatakan reliable atau handal jika jawaban seseorang terhadap pertanyaan adalah konsisten atau stabil dari waktu kewaktu. Kehandalan yang menyangkut kekonsistenan jawaban jika diujikan berulang pada sampel yang berbeda. SPSS memberkan fasilitas untuk mengukur realibilitas dengan uji statistic Cronbach Alpha $(\alpha)$ suatu konstruk atau variable dikatakan reliable jika memberikan nilai Cronbach Alpha>0.60 Ghozali (2013).

\subsection{Uji Normalitas}

Bertujuan untuk menguji apakah dalam model regresi, variabel pengganggu atau residual memiliki distribusi normal. Seperti diketahui bahwa ujit mengasumsikan bahwa nilai residual mengikuti distribusi normal. Kalau asumsi ini dilanggar maka uji statistik menjadi tidak valid Ghozali (2013).

- Histogram dimana berupa tampilan bentuk grafis untuk menunjukan distribusi data secara visual atau seberapa sering suatu nilai yang berbeda itu sering terjadi dalam suatu kumpulan data.

- Scatter Plot dimana sebuh grafik yang biasa digunakan untuk melihat suatu pola hubungan antara 2 variabel, agar bisa menggunakan scatter plot maka skala yang digunakan haruslah skala interval dan rasio

\subsection{Uji Regresi Linear Sederhana}


Tujuan dari teknik analisis Regresi Linear Sederhana adalah untuk prediksi bagaimana perubahan nilai yang terjadi pada variabel $\mathrm{X}$ dan variabel $\mathrm{Y}$ dimanipulasi (dinaikkan atau diturunkan nilainnya). Penelitian ini menggunakan analisis regresi linier sederhana. Menurut Sujarweni (2014) menjelaskan bahwa regresi liner sederhana merupakan regresi yang memiliki satu variabel dependen dan satu variabel idependen. Model persamaan regresi linier sederhana dengan menggunakan rumus sebagai berikut :

$$
\mathrm{Y}=\mathrm{a}+\mathrm{bX}
$$

Keterangan:

$\mathrm{Y}=$ Variabel dependen, yaitu Kepuasan konsumen

$\mathrm{a}=$ Konstanta, yaitu titik potong kurva tehadap sumbu $\mathrm{Y}$

$\mathrm{b}=$ Koefisien regresi, yaitu kemiringan kurva linear

$\mathrm{X}=$ Variabel independen, yaitu pengaruh Kualitas Produk

\subsection{Uji t}

Menurut Ghozali (2013) uji hipotesis adalah suatu prosedur yang akan menghasilkan sebuah keputusan, yaitu keputusan untuk menerima atau menolak hipotesis dengan menggunakan uji persial ( Uji t ):

$\mathrm{t}_{\text {hitung }}<\mathrm{t}_{\text {tabel }}=$ Ho diterima $($ Ha ditolak $)$

$t_{\text {hitung }}>t_{\text {tabel }}=$ Ho ditolak (Ha diterima)

1. Jika thitung $<$ ttabel berarti kualitas produk tidak berpengaruh siginfikan terhadap kepuasan konsumen sepeda motor NMAX pada PT. Yamaha A. Rivai Palembang.

2. Jika thitung>ttabel berarti kualitas produk berpengaruh signifikan terhadap kepuasan konsumen sepeda motor NMAX pada PT. Yamaha A. Rivai Palembang.

\subsection{Koefisien Korelasi (R)}

Tabel 1. Interprestasi koefisien korelasi (R)

\begin{tabular}{|c|c|}
\hline Besarnya Pengaruh & Tingkat Hubungan \\
\hline $0,00-0,199$ & Sangat lemah \\
\hline $0,20-0,339$ & Lemah \\
\hline $0,40-0,559$ & Sedang \\
\hline $0,60-0,799$ & Kuat \\
\hline $0,80-1,000$ & Sangat Kuat \\
\hline
\end{tabular}

Sumber: Sugiono (2014)

Koefisien korelasi adalah nilai yang menunjukan kuat/tidaknya hubungan linier antar dua variabel. Koefisien korelasi biasa di lambangkan dengan huruf $r$ dimana nilai $r$ dapat bervariasi dari -1 sampai +1 . Nilai $r$ yang mendekati -1 atau +1 menunjukan hubungan yang kuat antara dua variabel tersebut nilai $r$ yang mendekati 0 mengindikasikan lemahnya hubungan antara dua 
variabel tersebut. Sedangkan tanda + (Positif) dan - (Negatif) memberikan informasi mengenai arah hubungan antara dua varibel tersebut. Jika bernilai + (Positif) maka kedua variabel tersebut memiliki hubungan yang searah.

Dalam arti lain peningkatan $\mathrm{X}$ akan bersamaan dengan peningkatan $\mathrm{Y}$ dan begitu juga sebaliknya. Jika bernilai (Negatif) artinya korelasi antara kedua variabel tersebut bersifat berlawanan peningkatan nial $\mathrm{X}$ akan dibarengi dengan penurunan $\mathrm{Y}$, adapun untuk melihat hubungan atau korelasi, penulis menggunakan analisis yang dikemukakan oleh Sugiono (2014).

\subsection{Koefisien Determinasi $\left(R^{2}\right)$}

Menurut Ghozali (2016) koefisien determinasi $\left(\mathrm{R}^{2}\right)$ merupakan alat untuk mengukur seberapa jauh kemampuan model dalam menerangkan variasi variabel dependen. Nilai koefisien determinasi adalah antara nol atau satu. Nilai $\mathrm{R}^{2}$ yang kecil berarti kemampuan variabelvariabel independen dalam menjelaskan variasi variabel dependen amat terbatas. Dan sebaliknya jika nilai yang mendekati 1 berarti variabel-variabel independen memberikan hampir semua informasi yang dibutuhkan untuk memprediksi variabel-variabel tersebut.

\section{Hasil dan Pembahasan}

Tabel 2. Jenis kelamin responden

\begin{tabular}{|c|c|c|c|c|c|}
\hline \multicolumn{6}{|c|}{ Jenis Kelamin } \\
\hline & & Frequency & Percent & Valid Percent & Cumulative Percent \\
\hline \multirow[t]{3}{*}{ Valid } & Laki-laki & 29 & 58.0 & 58.0 & 58.0 \\
\hline & Perempuan & 21 & 42.0 & 42.0 & 100.0 \\
\hline & Total & 50 & 100.0 & 100.0 & \\
\hline
\end{tabular}

Tabel 3. Usia responden

\begin{tabular}{|c|c|c|c|c|c|}
\hline \multicolumn{2}{|c|}{ Umur } \\
\hline \multirow{7}{*}{} & Frequency & Percent & Valid Percent & $\begin{array}{c}\text { Cumulative } \\
\text { Percent }\end{array}$ \\
\hline \multirow{7}{*}{ Valid } & $20-25$ Tahun & 8 & 16.0 & 16.0 & 16.0 \\
\cline { 2 - 6 } & $26-30$ Tahun & 20 & 40.0 & 40.0 & 56.0 \\
\cline { 2 - 6 } & $31-40$ Tahun & 13 & 26.0 & 26.0 & 82.0 \\
\cline { 2 - 6 } & $41-50$ Tahun & 9 & 18.0 & 18.0 & 100.0 \\
\cline { 2 - 6 } & Total & 50 & 100.0 & 100.0 & \\
\hline
\end{tabular}

Responden pelanggan yang ada pada PT. Yamaha A. Rivai Palembang sebanyak 50 Kuesioner yang telah di kembalikan oleh responden yang telah dikembalikan oleh responden dan dapat 
digunakan dalam pengelolahan data. Dari hasil kuesioner yang di terima, dapat diketahui jenis kelamin responden. Tabel 2. menunjukan bahwa responden pelanggan di PT. Yamaha A. Rivai Palembang didominasi oleh laki-laki (58.0\%) sedangkan (42.0\%) diantaranya perempuan.

Berdasarkan table 3. diatas, dapat dilihat bahwa usia responden yang berusia 20-25 sebanyak 8 Orang (16.0\%). Usia 26-30 sebanyak 20 orang (40.0\%), Usia 31-40 sebanyak 13 orang $(26.0 \%)$, Usia 41-50 Tahun 9 orang (18\%).

Berdasarkan table 4. tingkat pendidikan responden adalah SMA sebanyak 12 orang sebesar (24.0\%), D3 sebanyak 21 orang sebesar $(42.0 \%)$, S1 sebanyak 13 orang sebesar $(26.0 \%)$ dan S2 sebanyak 4 orang dengan (8.0\%).

Berdasarkan Table 5. diatas, dapat dilihat Lama bekerja Responden 1-5 tahun sebanyak 18 orang sebesar (36.0\%), 6-10 tahun sebanyak 20 orang sebesar $(40.0 \%), 11-15$ tahun sebanyak 8 orang sebesar $(16.0 \%), 16-20$ tahun sebanyak 4 orang sebesar $(8.0 \%)$.

Tabel 4. Tingkat pendidikan responden

\begin{tabular}{|c|c|c|c|c|c|}
\hline \multicolumn{7}{|c|}{ Pendidikan Terakhir } \\
\hline \multirow{3}{*}{} & Frequency & Percent & Valid Percent & Cumulative Percent \\
\hline \multirow{6}{*}{ Valid } & SMA & 12 & 24.0 & 24.0 & 24.0 \\
\cline { 2 - 6 } & D3 & 21 & 42.0 & 42.0 & 66.0 \\
\cline { 2 - 6 } & S1 & 13 & 26.0 & 26.0 & 92.0 \\
\cline { 2 - 6 } & S2 & 4 & 8.0 & 8.0 & 100.0 \\
\cline { 2 - 6 } & Total & 50 & 100.0 & 100.0 & \\
\hline
\end{tabular}

Tabel 5. Lama bekerja responden

\begin{tabular}{|c|c|c|c|c|c|}
\hline \multicolumn{5}{|c|}{ Lama Bekerja } \\
\hline \multirow{7}{*}{} & Frequency & Percent & Valid Percent & $\begin{array}{c}\text { Cumulative } \\
\text { Percent }\end{array}$ \\
\hline \multirow{7}{*}{ Valid } & $1-5$ Tahun & 18 & 36.0 & 36.0 & 36.0 \\
\cline { 2 - 6 } & 6-10 Tahun & 20 & 40.0 & 40.0 & 76.0 \\
\cline { 2 - 6 } & $11-15$ Tahun & 8 & 16.0 & 16.0 & 92.0 \\
\cline { 2 - 6 } & $16-20$ Tahun & 4 & 8.0 & 8.0 & 100.0 \\
\cline { 2 - 6 } & Total & 50 & 100.0 & 100.0 & \\
\hline
\end{tabular}




\subsection{Uji Validitas}

Uji validitas dilakukan untuk mengukur tepat atau tidak indikator atau kuesioner dari masingmasing variabel. Pengujian dilakukan dengan membandingkan $r_{\text {hitung }}$ dengan rtabel dan menggunakan program SPSS. Selanjutnya pengujian validitas data dengan menggunakan uji dua sisi dengan taraf signifikan 0,05 . Pengujian validitas ini dilakukan terhadap 50 responden, maka rtabel $\mathrm{df}=\mathrm{N}-2$ dengan taraf signifikan $0,05 \mathrm{df}=50-2=48$, maka $\mathrm{r}$ tabel $=0,278$.

Tabel 6. Validitas kualitas produk (X)

\begin{tabular}{|c|c|c|c|}
\hline Item & $\mathrm{r}_{\text {hitung }}$ & $\mathrm{r}_{\text {tabel }}$ & Keterangan \\
\hline $\mathrm{X} 1$ & 0,504 & 0,278 & Valid \\
\hline $\mathrm{X} 2$ & 0,829 & 0,278 & Valid \\
\hline $\mathrm{X} 3$ & 0,745 & 0,278 & Valid \\
\hline $\mathrm{X} 4$ & 0,829 & 0,278 & Valid \\
\hline $\mathrm{X} 5$ & 0,461 & 0,278 & Valid \\
\hline $\mathrm{X} 6$ & 0,306 & 0,278 & Valid \\
\hline
\end{tabular}

Dari table 6. diatas dapat dilihat bahwa nilai $r$ hitung lebih besar dari $r$ tabel sehingga dapat disimpulkan bahwa seluruh data variabel Kualitas produk $(\mathrm{X})$ dinyatakan valid. Dengan data $\mathrm{r}$ hitung tertinggi 0,829 dan data terendah 0,306 data-data tersebut lebih besar dari $r$ tabel 0,278 dengan rata-rata $R_{\text {hitung }} 3,683$. Sehingga dapat dikatakan bahwa instrument pertanyaan yang digunakan variabel $(\mathrm{X})$ dinyatakan valid untuk dijadikan alat ukur penelitian ini.

Tabel 7. Validitas kepuasan konsumen (Y)

\begin{tabular}{|c|c|c|c|}
\hline Item & $\mathrm{r}_{\text {hitung }}$ & $\mathrm{r}_{\text {tabel }}$ & Keterangan \\
\hline Y1 & 0,425 & 0,278 & Valid \\
\hline Y2 & 0,419 & 0,278 & Valid \\
\hline Y3 & 0,678 & 0,278 & Valid \\
\hline Y4 & 0,725 & 0,278 & Valid \\
\hline Y5 & 0,477 & 0,278 & Valid \\
\hline
\end{tabular}

Dari tabel diatas dapat dilihat bahwa nilai $r$ hitung lebih besar dari $r$ tabel sehingga dapat disimpulkan bahwa seluruh data variabel Kepuasan konsumen (Y) dinyatakan valid. Dengan data $r$ hitung tertinggi 0,752 dan data terendah 0,419 data-data tersebut lebih besar dari $r$ tabel 0,278 dengan rata-rata $R_{\text {hitung }} 2,724$. Sehingga dapat dikatakan bahwa instrument pertanyaan yang digunakan variabel (Y) dinyatakan valid untuk dijadikan alat ukur penelitian ini. 


\subsection{Uji Reliabilitas}

Data untuk mengukur suatu kuesioner yang merupakan indikator dari variabel atau konstruk. Suatu kuesioner dikatakan reliable atau handal jika jawaban seseorang terhadap pertanyaan adalah konsisten atau stabil dari waktu kewaktu. Kehandalan yang menyangkut kekonsistenan jawaban jika diujikan berulang pada sampel yang berbeda. SPSS memberkan fasilitas untuk mengukur realibilitas dengan uji statistic Cronbach Alpha $(\alpha)$ suatu konstruk atau variable dikatakan reliable jika memberikan nilai Cronbach Alpha>0.60 Ghozali (2013).

Tabel 8. Uji reliabilitas

\begin{tabular}{|c|c|c|c|}
\hline Variabel & $\begin{array}{c}\text { Cronbach's } \\
\text { Alpha }\end{array}$ & $\begin{array}{c}\text { Standar } \\
\text { Reliabilitas }\end{array}$ & Keterangan \\
\hline Kualitas Produk & 0,742 & 0,60 & Reliabel \\
\hline Kepuasan Konsumen & 0,696 & 0,60 & Reliabel \\
\hline
\end{tabular}

Dari data tabel 8. diatas dilihat bahwa Cronbach's Aplha dari kedua variabel yaitu variabel Kualitas produk (X) 0,742 dan Kepuasan konsumen (Y) 0,696 yang mana keduanya $>0,60$ sehingga dapat dinyatakan bahwa data-data tersebut reliable untuk dijadikan alat ukur penelitian.

\subsection{Uji Normalitas}

Bertujuan untuk menguji apakah dalam model regresi, variabel pengganggu atau residual memiliki distribusi normal. Seperti diketahui bahwa ujit mengasumsikan bahwa nilai residual mengikuti distribusi normal. Kalau asumsi ini dilanggar maka uji statistik menjadi tidak valid Ghozali (2013).

1. Histogram dimana berupa tampilan bentuk grafis untuk menunjukan distribusi data secara visual atau seberapa sering suatu nilai yang berbeda itu sering terjadi dalam suatu kumpulan data.

2. Scatter Plot dimana sebuh grafik yang biasa digunakan untuk melihat suatu pola hubungan antara 2 variabel, agar bisa menggunakan scatter plot maka skala yang digunakan haruslah skala interval dan rasio.

Gambar 2. Hasil uji normalitas - histogram

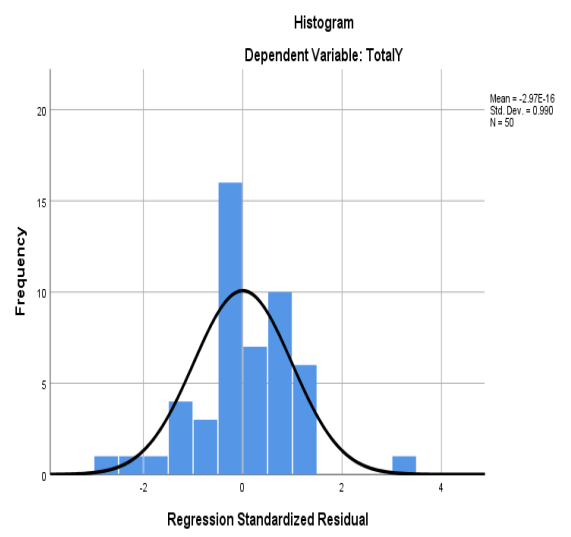


Berdasarkan gambar 4.5 di atas dapat diketahui bahwa grafik membentuk gunung atau lonceng, maka dengan ini data residual terdistribusi secara normal.

\section{Gambar 3. P-P plot of regression standardized residual}

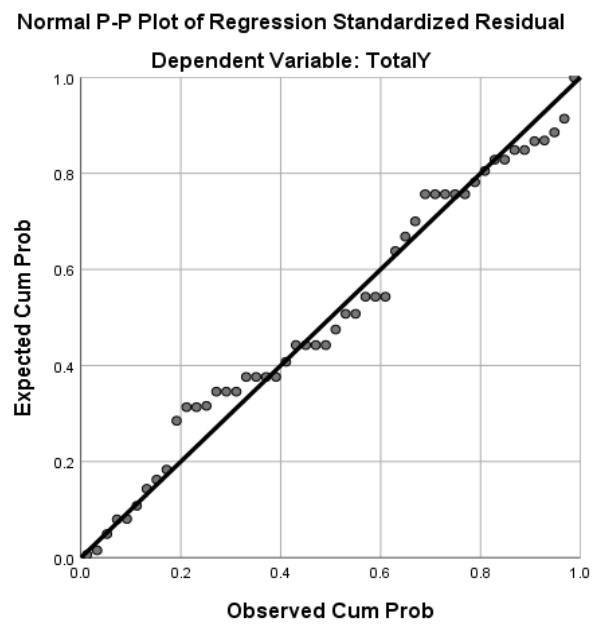

Bedasarkan gambar 4.6 diketahui grafik normal P-P Plot bahwa titik-titik menyebar sekitar garis dan mengikuti garis diagonal, dengan ini maka data residual terdistribusi secara normal.

\subsection{Uji Regresi Linear Sederhana}

Tujuan dari teknik analisis Regresi Linear Sederhana adalah untuk prediksi bagaimana perubahan nilai yang terjadi pada variabel $\mathrm{X}$ dan variabel $\mathrm{Y}$ dimanipulasi (dinaikkan atau diturunkan nilainnya). Penelitian ini menggunakan analisis regresi linier sederhana. Menurut Sujarweni (2014) menjelaskan bahwa regresi liner sederhana merupakan regresi yang memiliki satu variabel dependen dan satu variabel idependen. Model persamaan regresi linier sederhana dengan menggunakan rumus sebagai berikut:

$$
\mathrm{Y}=\mathrm{a}+\mathrm{bX}
$$

Keterangan:

$\mathrm{Y}=$ Variabel dependen, yaitu Kepuasan konsumen

$\mathrm{a}=$ Konstanta, yaitu titik potong kurva tehadap sumbu $\mathrm{Y}$

$\mathrm{b}=$ Koefisien regresi, yaitu kemiringan kurva linear

$\mathrm{X}=$ Variabel independen, yaitu pengaruh Kualitas Produk

Persamaan regresi Linear Sederhana tersebut jika dimasukan ke dalam persamaan regresi $\mathrm{Y}=\mathrm{a}+\mathrm{bX}$ dapat dijelaskan sebagai berikut :

$$
\mathrm{Y}=2.694+0,699 \mathrm{X}
$$

Dari persamaan regresi Liniear Sederhana diatas maka dapat dianalisis pengaruh variable Kualitas produk (X) terhadap variabel Kepuasan konsumen (Y), yaitu: Konstanta (a) mempunyai koefisien sebesar 2.694 sedangkan koefiesien regresi sebesar 0,699 maka dapat dikatakan variabel kualitas produk (X) berpengaruh positif terhadap variabel kepuasan konsumen (Y). jika diasumsikan variabel Kualitas produk (X) menunjukan besar kenaikan sebesar 1\% maka variabel Kepuasan konsumen (Y) akan mengalami kenaikan juga sebesar $69,9 \%$. 
Tabel 9. Uji regresi linear sederhana

\begin{tabular}{|c|c|c|c|c|c|c|}
\hline \multicolumn{7}{|c|}{ Coefficients $^{\mathrm{a}}$} \\
\hline \multirow{2}{*}{\multicolumn{2}{|c|}{ Model }} & \multicolumn{2}{|c|}{ Unstandardized Coefficients } & $\begin{array}{c}\text { Standardized } \\
\text { Coefficients }\end{array}$ & \multirow{3}{*}{$\frac{\mathrm{T}}{2.540}$} & \multirow{3}{*}{$\begin{array}{l}\text { Sig. } \\
.014\end{array}$} \\
\hline & & B & Std. Error & Beta & & \\
\hline \multirow[t]{2}{*}{1} & (Constant) & 2.694 & 1.061 & & & \\
\hline & TotalX & .699 & .046 & .910 & 15.209 & .000 \\
\hline
\end{tabular}

a. Dependent Variable: totally

\subsection{Uji $t$}

Menurut Ghozali (2013) uji hipotesis adalah suatu prosedur yang akan menghasilkan sebuah keputusan, yaitu keputusan untuk menerima atau menolak hipotesis dengan menggunakan uji persial ( Uji t ) :

$\mathrm{t}_{\text {hitung }}<\mathrm{t}_{\text {tabel }}=$ Ho diterima $\left(\mathrm{H}_{\mathrm{a}}\right.$ ditolak $)$

$t_{\text {hitung }}>\mathrm{t}_{\text {tabel }}=$ Ho ditolak $\left(\mathrm{H}_{\mathrm{a}}\right.$ diterima $)$

1. Jika thitung $<$ ttabel berarti kualitas produk tidak berpengaruh siginfikan terhadap kepuasan konsumen sepeda motor NMAX pada PT. Yamaha A. Rivai Palembang.

2. Jika thitung $>$ ttabel berarti kualitas produk berpengaruh signifikan terhadap kepuasan konsumen sepeda motor NMAX pada PT. Yamaha A. Rivai Palembang.

Tabel 10. Uji t

\begin{tabular}{|l|l|c|c|c|c|c|}
\hline \multicolumn{7}{|c|}{ Coefficients $^{\text {a }}$} \\
\hline \multicolumn{2}{|c|}{} & \multicolumn{3}{|c|}{ Unstandardized Coefficients } & $\begin{array}{c}\text { Standardized } \\
\text { Coefficients }\end{array}$ & \\
\cline { 3 - 8 } \multicolumn{2}{|l|}{ Model } & B & Std. Error & Beta & T & Sig. \\
\hline 1 & (Constant) & 2.694 & 1.061 & & 2.540 & .014 \\
\cline { 2 - 8 } & TotalX & .699 & .046 & .910 & 15.209 & .000 \\
\hline
\end{tabular}

a. Dependent Variable: totally

Bedasarkan data tabel 10. diperoleh $t$ hitung sebesar 15.209 dan Sig 0,000 Adapun Kriteriaditerimanya hipotesis :

- Jika Sig $<$ 0,05 maka Ho ditolak dan $\mathrm{H}_{1}$ diterima.

- Taraf nyata $=5 \%$ drajat kebebasan $(\mathrm{df})=\mathrm{n}-2=48$

Dari hasil perhitungan diatas diketahui bahwa nilai $t_{\text {hitung }}>\mathrm{t}_{\text {tabel }}<0.05$ yaitu $15.209>2.01$ hal 
ini berarti Ho ditolak dan $\mathrm{H}_{1}$ diterima, sehingga dapat disimpulkan bahwa kualitas produk berpengaruh signifikan terhadap kepuasan konsumen.

\subsection{Koefisen korelasi $(R)$}

Tabel 11. koefisien korelasi (R)

\begin{tabular}{|c|c|c|c|c|}
\hline \multicolumn{5}{|c|}{ Model Summary ${ }^{\mathrm{b}}$} \\
\hline Model & $\mathrm{R}$ & R Square & Adjusted R Square & $\begin{array}{c}\text { Std. Error of the } \\
\text { Estimate }\end{array}$ \\
\hline 1 & $.910^{\mathrm{a}}$ & .828 & .825 & 1.190 \\
\hline
\end{tabular}

a. Predictors: (Constant), TotalX

b. Dependent Variable: totally

Koefisien korelasi adalah nilai yang menunjukan kuat/tidaknya hubungan linier antar dua variabel. Koefisien korelasi biasa di lambangkan dengan huruf $r$ dimana nilai $r$ dapat bervariasi dari -1 sampai +1 . Nilai $r$ yang mendekati -1 atau +1 menunjukan hubungan yang kuat antara dua variabel tersebut nilai $r$ yang mendekati 0 mengindikasikan lemahnya hubungan antara dua variabel tersebut. Sedangkan tanda + (Positif) dan - (Negatif) memberikan informasi mengenai arah hubungan antara dua varibel tersebut. Jika bernilai + (Positif) maka kedua variabel tersebut memiliki hubungan yang searah.

Berdasarkan hasil perhitungan program SPSS dapat di interpretasikan sebagai berikut:Uji Koefisien korelasi (R) ini digunakan untuk mengukur berapa kuat hubungan antara variable Kualitas produk (X) dengan variabel kepuasan konsumen (Y), nilai korelasi (R) sebesar 0,910 yang berarti bahwa hubungan antara variabel Kualitas produk $(\mathrm{X})$ dengan variabel kepuasan konsumen (Y) adalah Sangat kuat (91\%).

\subsection{Koefisien Determinasi $\left(R^{2}\right)$}

Tabel 12. Koefisien determinasi $\left(\mathrm{R}^{2}\right)$

\begin{tabular}{|c|c|c|c|c|}
\hline \multicolumn{3}{|c|}{ Model Summary $^{\mathrm{b}}$} \\
\hline Model & $\mathrm{R}$ & R Square & $\begin{array}{c}\text { Adjusted R } \\
\text { Square }\end{array}$ & Std. Error of the Estimate \\
\hline 1 & $.910^{\mathrm{a}}$ & .828 & .825 & 1.190 \\
\hline
\end{tabular}

a. Predictors: (Constant), TotalX

b. Dependent Variable: totally

Menurut Ghozali (2016) koefisien determinasi $\left(\mathrm{R}^{2}\right)$ merupakan alat untuk mengukur seberapa jauh kemampuan model dalam menerangkan variasi variabel dependen. Nilai koefisien determinasi adalah antara nol atau satu. Nilai $\mathrm{R}^{2}$ yang kecil berarti kemampuan variabelvariabel independen dalam menjelaskan variasi variabel dependen amat terbatas. Dan 
sebaliknya jika nilai yang mendekati 1 berarti variabel-variabel independen memberikan hampir semua informasi yang dibutuhkan untuk memprediksi variabel-variabel tersebut.

Hasilnya sebagai berikut: $\mathrm{R}^{2}=0,828 \times 100 \%=82,8 \%$

Uji Koefisien determinasi $\left(\mathrm{R}^{2}\right)$ ini digunakan untuk mengetahui seberapa besar kemampuan variabel Kualitas produk $(\mathrm{X})$ dalam menjelaskan variabel kepuasan konsumen, Nilai koefisien determinasi $\left(\mathrm{R}^{2}\right)$ sebesar $82,8 \%$ selebihnya $17,2 \%$ dipengaruhi oleh variabel lainnya.

\section{Kesimpulan}

Berdasarkan hasil penelitian dan pembahasan yang telah diuraikan diatas maka dapat ditarik kesimpulan sebagai berikut:

a. Hasil penelitian dari variabel kualitas produk menunjukan $t_{\text {hitung }}>t_{\text {tabel }}\left(15.209>t_{\text {tabel }} 2.01\right)$ dan taraf sig $(0,000<0,05)$. Jadi dapat disimpulkan variabel Kualitas Produk (X) berpengaruh secara signifikan terhadap Kepuasan Konsumen (Y) Sepeda Motor Yamaha NMAX Pada PT. Yamaha A. Rivai Palembang.

b. Hasil penelitian pada analisa regresi linier sederhana diperoleh nilai koefisien regresi dari variabel Kualitas Produk (X) sebesar 0,699. dapat disimpulkan nilai variabel Kepuasan Konsumen akan meningkat sebesar 69,9\% jika kualitas produk (X) naik sebesar 1\%.

c. Hasil uji Koefisien Korelasi (R) diperoleh nilai sebesar 0,910. hal inidapat disimpulkan hubungan antara Kualitas Produk (X) dengan Kepuasan Konsumen (Y) adalah sangat kuat sebesar (91\%).

d. Hasil dari Koefisien Determinasi $\left(\mathrm{R}^{2}\right)$ diperoleh nilai sebesar 0,828. hal ini memberikan makna besarnya kontribusi variable kualitas produk $(\mathrm{X})$ bisa menjelaskan variabel Kepuasan Konsumen (Y) sebesar 82,8\% sisanya sebesar 17,2\% bisa dijelaskan atau dipengaruhi oleh variabel lain yang tidak dimasukkan dalam penelitian ini.

Dari hasil penelitian ini, analisis data, pembahasan dan kesimpulan maka saran yang diberikan:

a. Untuk perusahaan PT. Yamaha Palembang agar tetap menjaga dan meningkatkan kualitas produk sepeda motor Yamaha NMAX guna meningkatkan kepuasan konsumen speda motor NMAX. Dengan cara selalu melakukan inovasi yang baru dan lebih canggih dalam menciptakan desain kendaraan sepeda motor Yamaha NMAX yang lebih menarik dan nyaman dikendarai sesuai dengan perkembangan industry otomotif Indonesia.

b. Untuk peerusahaan PT. Yamaha Palembang agar selalu mengutamakan kualitas produk guna memenuhi kepuasan konsumen, seperti meningkatkan daya tahan komponen komponen yang terdapat pada speda motor Yamaha NMAX agar membuat konsumen loyal terhadap sepeda motor Yamaha NMAX.

c. Untuk penelitian selanjutnya diharapkan dapat mengkaji lebih mendalam tentang variabel Kualitas produk (X) dan variabel Kepuasan konsumen (Y) pada lokasi lainnya. Dengan memasukan atau menambahkan variabel lain seperti pengaruh promosi, pengaruh harga, dan inovasi produk agar model konseptual untuk penelitian kedepan semakin komplek dan dapat memberikan kontribusi bagi pengembangan ilmu pengetahuan.

d. Untuk penelitian selanjutnya diharapkan dapat mengembangkan atau memaksimalkan penelitian terhadap sepeda motor Yamaha NMAX pada type terbaru. 


\section{Referensi}

Alma, Buchari. 2016. Manajemen Pemasaran dan Pemasaran Jasa. Bandung: Alfabeta.

Arikunto, S. (2013). Prosedur Penelitian: Suatu Pendekatan Praktik. Jakarta: Rineka Cipta.

Ghozali, I. (2013). Metode Penelitian. Bandung: Pustaka Setia.

Ghozali, I. (2016). Aplikasi Analisis Multivariate dengan Program IBM SPSS 23. Semarang: BPFE Universitas Diponegoro.

Kotler, Philip. dan Keller, Kevin lane. (2009). Manajemen Pemasaran. (13th ed., Vol. 1). Jakarta: Erlangga.

Kotler, P. dan Keller. 2016. Marketing Manajemen. Edisi 14. Global Edision Pearson. Prentice. Hal. 156.

Kotler, P. dan Amstrong,G. 2010. Principles of marketing. Thirtheen Edition. Prentice Hall. New Jersey.

Mahendra, S. 2014. Pengaruh kualitas produk dan harga terhadap kepuasan konsumen Honda Beat. Jurnal Ilmu Manajemen Vol. 2 No. 1.

Nugroho, T, D. 2015. Analisis Pengaruh Produk, Harga Dan Promosi Terhadap

Keputusan Konsumen Dalam Pembelian Rokok Surya. Jurnal Riset Mahasiswa Manajemen (JRMM) Vol. 3 No. 1.

Sangadji, Dr Etta Mamang, M.Si dan Dr. Sopiah, M.M., Mpd. 2013. Perilaku Konsumen Pendekatan Praktis Disertasi Himpunan Jurnal Penelitian. Yogyakarta: Penerbit Andi.

Setyo, P.E. 2017. Pengaruh Kualitas Produk Dan Harga Terhadap kepuasan Konsumen "Best Autoworks". Jurnal Manajemen Dan Start-Up Bisnis Vol. 1. No. 6. Hal. 755-764.

Sugiyono. 2014. Metode Penelitian kuantitatif kualitatif $R \& D$. Bandung: Alfabeta. Sugiyono. (2016). Metode Penelitian Kuantitatif, Kualitatif dan R\&D. Bandung: PT Alfabet.

Sujarweni, W. (2014). Metodelogi Penelitian. Yogyakarta: Pustaka Baru Press.

Tjiptono, Fandy dan Gregorius Chandra. 2012. Pemasaran Strategik. Yogyakarta, Andi. 